\title{
PENEBARAN IKAN BANDENG DI WADUK JATILUHUR: Analisis Dampak dan Kebijakan Pengembangan
}

\author{
Sonny Koeshendrajana ${ }^{1}$, Tenny Apriliani ${ }^{1}$, Maulana Firdaus ${ }^{1}$, Zahri Nasution ${ }^{1}$ dan \\ Amula Nurfiarini $^{2}$ \\ ${ }^{1}$ Balai Besar Penelitian Sosial Ekonomi Kelautan dan Perikanan, \\ Jalan Petamburan VI, SLIPI-Jakarta 10260. \\ Email: sonny_koes@yahoo.com \\ ${ }^{2}$ Balai Penelitian Pemulihan dan Konservasi Sumber Daya Ikan, \\ Jalan Cilalawi, Jatiluhur-Purwakarta
}

Diterima 27 Oktober 2011 - Disetujui 11 Desember 2011

\begin{abstract}
ABSTRAK
Penebaran ikan bandeng merupakan salah satu opsi pengelolaan yang dilakukan untuk memperbaiki kualitas perairan yang semakin menurun di Waduk Jatiluhur. Penebaran ikan bandeng ke perairan waduk Jatiluhur secara sistematis telah dilakukan sejak tahun 2008, namun demikian, manfaat yang dapat dirasakan belum banyak mendapat perhatian. Penelitian bertujuan untuk mengevaluasi secara sosial ekonomi dampak penebaran ikan bandeng di perairan Waduk Jatiluhur sebagai basis pengembangan di masa mendatang telah dilakukan. Penelitian di lapang menunjukkan bahwa penebaran bandeng memberikan dampak bagi kualitas sumberdaya perairan serta kondisi sosial ekonomi masyarakat. Berdasarkan pertimbangan-pertimbangan tersebut maka beberapa rumusan kebijakan yang perlu ditindak lanjuti adalah: (i) mengkaji dampak penebaran ikan bandeng terhadap pertumbuhan ikan budidaya dalam karamba; (ii) melakukan ujicoba penebaran dengan jenis ikan lainnya yang mampu bereproduksi secara alamiah di perairan waduk dan tidak menganggu kestabilan dinamika populasi ikan; (iii) penguatan kelembagaan penebaran ikan, serta; (iv) melakukan sosialisasi lebih intensif mengenai perlunya kesadaran masyarakat untuk menjaga kelestarian sumber daya perairan.
\end{abstract}

Kata Kunci: dampak, sosial ekonomi, penebaran ikan, waduk Jatiluhur

Abstract: Introducing Milkfish in the Jatiluhur Reservoir: Analysis of Impacts and Policies Development. By: Sonny Koeshendrajana, Tenny Apriliani, Maulana Firdaus, Zahri Nasution, and Amula Nurfiarini

Introducing milkfish is considered one of management options to improve water quality in the Jatiluhur reservoir. This activity has been systematically carried out since 2008; however, tangible benefits from this activity are less coverage. This research aimed to evaluate socio-economic impacts of milkfish stocking in the Jatiluhur reservoir that can be used as a basis for future fisheries development in this reservoir. Results of this research show that milkfish-stocking in the Jatiluhur reservoir contributed to the improvement of its aquatic resources environment and socio-economic conditions of the society. Based on these findings, several policies recommendation should be followed up and implemented, namely (i) immediately assess the impact of milkfish stocking to the growth of fish cultured in the cage; (ii) stocking different fish species that enable to reproduce naturally in the reservoir waters without disturbing population dynamic of fish stock; (iii) strengthening institution of the fish stocking program, and (iv) intensify dissemination and people awareness to conserve aquatic resources.

Keywords: impact, social economics, fish introduced, Jatiluhur reservoir 


\section{PENDAHULUAN}

Penebaran ikan Bandeng (Chanos chanos) di perairan waduk Jatiluhur atau waduk Ir H. Juanda merupakan salah satu opsi pengelolaan yang dilaksanakan sebagai upaya mengurangi dampak negatif usaha budidaya ikan dalam karamba jaring apung. Berdasarkan hasil penelitian yang dilakukan oleh pakar dari berbagai institusi (Nastiti et al., 2001; Kartamihardja, 2007; BRPSI, 2009) sejak tahun 2001 hingga sekarang, Waduk Jatiluhur telah berada pada fase kemantapan kesuburan optimal yakni termasuk tipe perairan dengan klasifikasi tingkat kesuburan tinggi (eutrophic). Tingkat kesuburan yang tinggi tersebut di samping diakibatkan oleh proses dinamik secara alami, juga dipicu dari adanya aktifitas budidaya ikan dalam Karamba Jaring Apung (KJA) sebagai dampak tidak termanfaatkannya pakan pada budidaya ikan di karamba jaring apung.

Kondisi eutrophic tersebut, apabila tidak dilakukan tindakan yang tepat akan berakibat buruk pada lingkungan sumber daya perairan waduk dan berpotensi menyebabkan penurunan umur teknis turbin penggerak pembangkit listrik tenaga air. Hasil pertemuan ilmiah, baik berupa seminar, lokakarya/workshop maupun round table discussion yang telah dilakukan selama 5 tahun terakhir, memberikan indikasi bahwa salah satu pendekatan penyelesaian masalah tersebut di atas secara biologi dalam bentuk penebaran ikan yang bersifat 'plankton feeder', sebagai contoh ikan nilem (Ostheochilus hasselti), ikan mola (grass carp), ikan patin (Pangasius hypothalmus), ringo (Thynnichthys Thynnoides) dan ikan Bandeng (Chanos chanos).

Hasil penelitian Balai Riset Pemulihan Sumber daya Ikan (2009) dan disertasi Kartamihardja (2007) merekomendasikan agar dilakukan penebaran ikan Bandeng di perairan waduk Jatiluhur. Pemilihan jenis ikan tersebut didasarkan pada sifat pemakan plankton (plankton feeder) dan kemampuan mengisi relung yang belum termanfaatkan di perairan waduk Jatiluhur. Selain pertimbangan tersebut di atas, secara sosial ekonomi ikan Bandeng mempunyai nilai jual yang relatif tinggi dan biasa dikonsumsi masyarakat dari berbagai kelompok golongan pendapatan.

Penebaran ikan ke dalam perairan waduk Jatiluhur secara historis telah dilakukan sejak waduk resmi dioperasikan tahun 1965 (Sarnita, 1976). Sampai dengan tahun 2009 tercatat sebanyak 14 jenis ikan ditebarkan yang umumnya merupakan jenis ikan budidaya yang di antaranya tidak cocok dengan lingkungan perairan seperti ikan sepat siam (Trichogaster pectoralis), sepat rawa (Trichogaster tricopterus), gurame (Osphronemus gouramy), tembakang (Helostoma temminckii), nila (Oreochromis niloticus), sedang jenis lainnya adalah ikan mola, patin, Bandeng, nilem, (Sarnita, 1976; 1999; Kartamihardja dan Hardjamulia, 1983; Kartamihardja dan Umar, 2005, Kartamihardja, 2009). Penebaran ikan Bandeng di perairan waduk Jatiluhur pada awalnya dilakukan secara tidak sengaja kemudian berdasarkan hasil penelitian, ikan Bandeng tersebut dapat tumbuh dengan cepat bila dibanding dengan di pelihara pada habitat aslinya (air bersalinitas).

Meskipun demikian, ikan Bandeng dalam perkembangannya memiliki keterbatasan tidak dapat berkembang biak secara alami di perairan tawar, sehingga untuk keberlanjutannya diperlukan sistem penebaran ulang secara periodik. Sebagai suatu program, penebaran ikan Bandeng ke perairan waduk Jatiluhur secara sistematis telah dilakukan sejak tahun 2008, namun demikian, selama ini manfaat yang dapat dirasakan belum banyak mendapat perhatian. Sementara itu, ada kecenderungan ke depan bahwa ikan Bandeng ini akan ditebarkan juga ke berbagai perairan tawar di seluruh Indonesia. Oleh karena itu, makalah ini bertujuan untuk mengevaluasi secara sosial ekonomi dampak penebaran ikan Bandeng di perairan Waduk Jatiluhur perlu dilakukan sehingga hasil yang akan diperoleh tersebut dapat dijadikan basis ataupun pertimbangan di masa mendatang. 


\section{METODOLOGI}

\section{Lokasi dan Waktu Penelitian}

Penelitian ini dilakukan selama 2 bulan (September-Oktober 2010) di Waduk Jatiluhur, Kabupaten Purwakarta. Kegiatan penelitian bersifat analisis kebijakan. Dalam pelaksanaannya, kegiatan yang dilakukan meliputi pengumpulan data primer dan sekunder serta verifikasi lapang. Studi literatur, analisis dan pengolahan data serta interpretasi dan pelaporan.

\section{Jenis dan Sumber Data}

Data yang akan dikumpulkan dan digunakan dalam studi ini yaitu data primer dan data sekunder. Data primer yang dimaksudkan adalah hasil survai lapang berupa pengamatan dan observasi. Pengambilan data primer dilakukan dengan bantuan pertanyaan bersifat tematik dan kuesioner terstruktur. Pengambilan data primer ke lapang difokuskan pada verifikasi data-data yang telah diperoleh. Data sekunder yang dikumpulkan adalah laporan hasil studi terdahulu terkait penebaran ikan dan kegiatan perikanan di perairan waduk Jatiluhur. Pengumpulan data dilakukan dengan menggunakan metoda survai dengan bantuan atribut penelitian Rencana Operasional Kegiatan Riset (ROKR) dan Kuisioner. Data primer dilakukan dengan cara wawancara dengan responden serta wawancana mendalam dengan informan kunci yang mengetahui informasi terkait dengan kegiatan penebaran ikan Bandeng di Waduk Jatiluhur serta instansi terkait lainnya.

\section{Metode Analisis}

Data hasil studi baik sekunder maupun primer diolah dan diverifikasi selanjutnya dianalisis secara deskriptif dan diinterpretasikan secara logis (Nazir, 1988). Kemudian, dilakukan Content Analysis terhadap kebijakan saat ini; sedangkan terhadap kebijakan yang akan direkomendasikan dilakukan analisis dan verifikasi melalui seminar dan atau lokakarya yang mengundang para pakar guna mendapatkan masukan untuk perbaikan hasil kajian.

\section{WADUK JATILUHUR DAN PEMANFAATANNYA}

Waduk Ir. H. Djuanda atau lebih dikenal dengan nama waduk Jatiluhur dibangun pada awal tahun 1957 dan dinyatakan selesai pada tahun 1967 serta kemudian dikelola oleh Perusahaan Negara (PN) Jatiluhur (1967 1970). Waduk Jatiluhur terletak pada Kabupaten Purwakarta, Propinsi Jawa Barat. Pemerintah melalui Peraturan Pemerintah (PP) nomor 94 tahun 1999 tentang pengelolaan, perlindungan, pemanfaatan dan pengembangan waduk Ir. $\mathrm{H}$. Djuanda membentuk badan otorita pengelola yaitu Perum Jasa Tirta II (PJT II). Berdasarkan PP tersebut kewenangan PJT II yaitu sebagai Badan Usaha Milik Negara (BUMN) pengelola air dan atau sumber air.

Waduk Jatiluhur mempunyai luas 8.300 Ha dengan kapasitas waduk mencapai \pm 3 milyar $\mathrm{m}^{3}$ dan duga muka air maksimum mencapai \pm 107 meter dpl. Waduk ini merupakan waduk serbaguna dengan peruntukkan bagi pembangkit listrik tenaga air (PLTA), penyediaan bahan baku air minum dan industri, penyediaan air irigasi, perikanan, pariwisata dan pengendalian banjir. Sumber air waduk Jatiluhur berasal dari Daerah Aliran Sungai (DAS) Citarum yaitu, daerah pengaliran waduk Saguling dan Cirata.

Jenis sumber daya ikan di perairan waduk beragam dan termasuk dalam jenis ikan yang memiliki nilai ekonomi tinggi. Namun dengan adanya usaha KJA menyebabkan perubahan komposisi ikan dan ada beberapa jenis ikan yang mengalami kepunahan (Krismono et al. (1983) dalam Purnamaningtyas et al. (2008)). Komposisi ikan sebelum dan setelah kegiatan budidaya disajikan pada Tabel 1 .

Pola pemanfaatan sumber daya perairan umum Waduk Djuanda terdiri dari banyak aspek antara lain (1) Perikanan yang berupa perikanan tangkap dan perikanan budidaya keramba jaring apung (KJA); (2) Transportasi; (3) Pariwisata; (4) PLTA; dan (5) Sebagai penyedia air minum. 
Tabel 1. Komposisi Ikan di Perairan Waduk Jatiluhur.

Table 1. Fish Composition in the Jatiluhur Reservoir.

\begin{tabular}{ll}
\hline $\begin{array}{c}\text { Sebelum Adanya KJA/ Before Existing of Floating } \\
\text { Cage Net }\end{array}$ & $\begin{array}{c}\text { Setelah Adanya KJA/ After Existing of Floating } \\
\text { Cage Net }\end{array}$ \\
\hline Tagih (Mytus nemurus) & Nila (Oreochromis niloticus) \\
Hampal (Hampala macrolepidota) & Bandeng (Channos channos) \\
Jambal (Pangasius hypopthalmus) & Betutu (Oxyeleotris marmorata) \\
Tawes (Barbodes javanicus) & Goldsom (Astronotus ocellatus) \\
Kebogerang (Mytus nigriceps) & Selebra (Parachromis managuensis) \\
Udang (Macrobrachium sp.) & Oskar (Amphilophus citrinellus) \\
Nila (Oreochromis niloticus) & Ikan kaca (Chanda punctulada) \\
Lalawak (Barbonymus balaroides) & \\
Genggehek (Mystacoleucus marginatus) & \\
Balidra (Notopterus chitala) & \\
\hline
\end{tabular}

Sumber : Krismono, et al., 1983.

Source : Krismono, et al., 1983.

\section{STATUS DAN PERMASALAHAN PERIKANAN}

Kegiatan perikanan di Waduk Jatiluhur pada awalnya hanya sebatas kegiatan penangkapan ikan usaha rakyat dengan menggunakan peralatan tradisional yang bertujuan hanya untuk memenuhi kebutuhan hidup rumah tangga sehari-hari. Namun semenjak diintroduksikannya teknik budidaya dalam keramba jaring apung, maka kegiatan budidaya berkembang dengan pesat. Pada tahun 1988 keramba jaring apung di waduk Jatiluhur hanya berjumlah 15 unit, namun hingga akhir tahun 2009 telah berkembang lebih dari 7.000 unit (Sutardjo, 2000 dan Dinas Peternakan dan Perikanan Kabupaten Purwakarta, 2009).

Perikanan waduk bertujuan untuk meningkatkan produksi ikan dan mempertahankan produksi tersebut pada tingkat produktivitas maksimumnya, baik untuk kegiatan perikanan tangkap maupun budidaya. Untuk produktivitas usaha penangkapan mengalami fluktuatif, ada beberapa faktor yang mempengaruhi kondisi tersebut, antara lain adalah jumlah populasi ikan yang tersedia di alam, jumlah nelayan yang melakukan penangkapan, teknologi penangkapan yang digunakan serta tinggi permukaan air. Biasanya pada saat permukaan air tinggi (musim hujan) merupakan musim paceklik bagi para nelayan di Waduk Jatiluhur, karena ikan menyebar keseluruh badan waduk sehingga sulit untuk tertangkap, sedangkan usaha budidaya produktivitasnya selalu mengalami penurunan tiap tahunnya, seperti yang tercantum pada Tabel 2.

Ada beberapa faktor yang menyebabkan produktivitas usaha budidaya ikan di Waduk Jatiluhur selalu mengalami penurunan, antara lain yang utama adalah penurunan kualitas air akibat limbah organik yang timbul dari pakan yang diberikan, semakin bertambahnya jumlah $\mathrm{KJA}$, benih ikan serta kualitas pakan. Pada mulanya kegiatan budidaya ikan dalam keramba jaring apung merupakan salah satu primadona alternatif pekerjaan bagi masyarakat, namun pada kenyataanya saat ini menimbulkan efek boomerang bagi pembudidaya itu sendiri maupun pihak lain yang memanfaatkan Waduk Jatiluhur.

Keberhasilan usaha budidaya di Waduk Jatiluhur memberikan stimulus kepada masyarakat baik di sekitar Waduk maupun diluar wilayah Kabupaten Purwakarta untuk menginvestasikan uangnya dalam berbudidaya, sehingga dampaknya yaitu jumlah KJA yang ada sudah melebihi kapasitas yang diijinkan oleh pemerintah. Tidak jarang para pembudidaya yang mendirikan KJA di Waduk Jatiluhur tanpa surat ijin dan mendirikan KJA diluar wilayah 
Tabel 2. Perkembangan Produktivitas Usaha Penangkapan dan Usaha Perikanan Budidaya Ikan di Waduk Jatiluhur, 2005-2009.

Table 2. Development of Capture and Aquaculture Fisheries Productivity in the Jatiluhur Reservoir, 2005-2009.

\begin{tabular}{|c|c|c|c|c|c|}
\hline \multirow{2}{*}{ Kategori/ Categorize } & \multicolumn{5}{|c|}{ Tahun/ Year } \\
\hline & 2005 & 2006 & 2007 & 2008 & 2009 \\
\hline \multicolumn{6}{|l|}{$\begin{array}{l}\text { Produktivitas Usaha Penangkapan/ Capture Fishery } \\
\text { Productivity }\end{array}$} \\
\hline $\begin{array}{l}\text { - Produksi per nelayan }(\mathrm{kg} / \mathrm{th}) / \text { Production per } \\
\text { fishers }(\mathrm{kg} / \mathrm{yr})\end{array}$ & 736 & 620 & 358 & 430 & 330 \\
\hline $\begin{array}{l}\text { - Produktivitas per alat }(\mathrm{kg} / \mathrm{th}) / \text { Productivity per } \\
\text { fishing gear ( } \mathrm{kg} / \text { year) }\end{array}$ & 322 & 260 & 284 & 343 & 321 \\
\hline \multicolumn{6}{|l|}{$\begin{array}{l}\text { Produktivitas Perikanan Budidaya/ Aquaculture } \\
\text { Productivity }\end{array}$} \\
\hline $\begin{array}{l}\text { - Produktivias per pembudidaya }(\mathrm{kg} / \mathrm{th}) \mathrm{)} / \\
\text { Production per fish-farmer (kg/year) }\end{array}$ & 23,165 & 35,792 & 29,283 & 36,461 & 33,028 \\
\hline $\begin{array}{l}\text { - Produktivitas per kantong }(\mathrm{kg} / \mathrm{th}) / \text { Productivity per } \\
\text { Cage (kg/year) }\end{array}$ & 5,529 & 3,665 & 3,829 & 3,046 & 2,249 \\
\hline
\end{tabular}

Sumber : Departemen Kelautan dan Perikanan (DKP) dan Australian center for International Agricultural Research (ACIAR), 2007.

Source : Ministry of Marine Affairs and Fisheries and Australian center for International Agricultural Research (ACIAR), 2007.

zona yang telah ditentukan. Kondisi tersebut semakin memperburuk keadaan tata ruang waduk dan tentu saja akan membahayakan bagi kelestarian lingkungan. Berdasarkan informasi yang diperoleh dari PJT II, selain menyebabkan penurunan kualitas air, limbah yang ditimbulkan dari kegiatan budidaya ini pun dapat mempercepat korosi (karat) pada turbin maupun jenis alat lainnya yang terbuat dari logam.

Berdasarkan fakta yang terjadi terhadap penurunan kualitas perairan akibat dari limbah organik, maka salah satu upaya untuk menanggulanginya yaitu dengan cara melakukan penebaran ikan yang bersifat plankton feeder seperti ikan nila, tawes, mola, Bandeng dan lainnya, karena limbah organik dari kegiatan budidaya memacu kesuburan plankton dan alga di perairan, sehingga pada saat kondisi jenuh akan membahayakan biota yang ada diperairan, termasuk ikan didalamnya.

\section{PENEBARAN IKAN BANDENG}

Ikan Bandeng merupakan salah satu jenis ikan pemakan plankton (plankton feeder).
Penebaran ikan Bandeng di Waduk Ir. H Juanda diharapkan mampu mengisi relung yang belum termanfaatkan di perairan secara optimal. Selain pertimbangan tersebut di atas, secara sosial ekonomi ikan Bandeng mempunyai nilai jual yang relatif tinggi dan biasa dikonsumsi masyarakat dari berbagai kelompok golongan pendapatan, sehingga diharapkan juga akan mampu memberikan dampak cukup baik bagi masyarakat perikanan khususnya nelayan di perairan tersebut.

Penebaran ikan Bandeng di perairan waduk Jatiluhur, seperti yang telah disampaikan sebelumnya pada awalnya adalah dilakukan secara tidak sengaja pada tahun 2005. Pada saat itu kondisi perairan waduk berada pada level eutrofik. Berdasarkan hasil penelitian, ikan Bandeng tersebut dapat tumbuh dengan cepat bila dibandingkan dengan dipelihara pada habitat aslinya (air bersalinitas). Meskipun demikian, ikan Bandeng dalam perkembangannya memiliki keterbatasan tidak dapat berkembangbiak secara alami di perairan tawar, sehingga untuk keberlanjutannya diperlukan sistem penebaran ulang secara periodik. 
Sebagai suatu program, penebaran ikan Bandeng ke perairan waduk Jatiluhur secara sistematis telah dilakukan sejak tahun 2008 melalui rekomendasi project kerjasama antara Kementerian Kelautan dan Perikanan dan ACIAR. Hingga tahun 2010 telah dilakukan dua tahap penebaran dengan total benih yang ditebar mencapai 6,9 juta atau sekitar $57,5 \%$ dari total benih yang direncanakan. Penebaran di bagi dalam dua tahap, yakni, tahap I tahun 2008, dilaksanakan selama kurun waktu 1 bulan (Juli-Agustus 2008) sebanyak 2.116.000 ekor, dan tahap dua tahun 2009 yang direncanakan diselesaikan dalam kurun waktu 4 bulan (Oktober-Januari 2010) sebanyak 10.000 .000 ekor. Namun dalam implementasinya, hingga saat ini tahap dua baru terealisasi sekitar 4.787.231 ekor $(47,8 \%)$ dari total benih yang akan ditebar.

Keberhasilan penebaran Bandeng ini disamping laju pertumbuhannya yang tinggi, tetapi juga kemampuannya memanfaatkan kelimpahan plankton yang tinggi. Hal tersebut diketahui dari hasil analisa isi perut ikan Bandeng yang dilakukan oleh tim peneliti LRPSI, menunjukkan bahwa ikan Bandeng ini mempunyai makanan utama fitoplankton dan zooplankton dengan komposisi pakan 63,7\% dan $34,6 \%$, dan sisanya dari jenis makrofita dan detritus masing-masing sebesar $0,3 \%$ dan $1,4 \%$. Sehingga dapat disimpulkan bahwa ikan ini termasuk dalam golongan herbivora.

Hasil pengamatan kegiatan penebaran tahap 2 (tahun 2009/2010) sampai dengan bulan Juli 2010, tercatat telah ditebar sebanyak 18 trip, dengan total benih sebanyak 4.859.800 ekor (Tabel 1). Penebaran terakhir dilakukan tanggal 21 Juli 2010. Terhambatnya pelaksanaan penebaran Bandeng di lapangan lebih disebabkan karena kekosongan produksi juvenil dari tambak Pandu Karawang, serta permasalahan kondisi waduk yang mengalami pasang sangat tinggi selama bulan tersebut, menjadi penyebab untuk belum melanjutkan kegiatan penebaran.

Pertumbuhan ikan Bandeng yang dilakukan pada minggu ke IV bulan januari 2010 (awal panen raya), menunjukkan bahwa di zona 5 ikan Bandeng tebaran telah berukuran antara 250 - 300 gram/ekor, sedangkan di zona 1,2, dan 3 ikan Bandeng berkisar antara 120 -250 gram/ekor. Sedangkan perkembangan pertumbuhan Bandeng selanjutnya, diketahui bahwa pada bulan mei, Bandeng tebaran yang tertangkap telah berukuran panjang antara 25-31 cm dengan berat rata-rata 350-700 gram/ekor. Namun secara kualitas, ikan Bandeng dari waduk Jatiluhur lebih rendah dibandingkan dengan Bandeng dari tambak air payau sebab daging ikan Bandeng dari Waduk jatiluhur lebih lembek dan sisiknya mudah lepas, hal tersebut menyebabkan harga Bande ng jatiluhur semakin merosot.

\section{DAMPAK PENEBARAN IKAN BANDENG DI WADUK JATILUHUR}

Waduk Ir. H. Djuanda mempunyai luas 8.300 ha dengan kedalaman maksimum 97 m, dan luas daerah limnetiknya berkisar antara 5.200-7.100 ha atau 63-86 \% dari luas total (Kartamihardja, 2007). Perkembangan budidaya ikan dalam KJA di waduk ini telah berkembang dengan pesat, bahkan telah melampaui daya dukung perairan itu sendiri. Unsur hara ( $N$ dan P) yang dihasilkan dari kegiatan budidaya ikan dalam KJA di waduk ini pada tahun 1996 ditaksir sebesar $36.531,3$ ton untuk total $\mathrm{N}$ dan 33.968,4 ton untuk total P (Nastiti et al., 2001).

Peningkatan unsur hara tersebut telah berdampak terhadap peningkatan pertumbuhan fitoplankton yang tingi dalam waktu yang singkat (blooming). Daerah limnetik yang kaya akan fitoplankton tersebut dihuni oleh jenis pemakan plankton yang sangat sedikit. Hasil penelitian aliran energi biomassa di zona limnetik oleh Kartamihardja (2007) menunjukan bahwa untuk meningkatkan optimasi pemanfaatan plankton di zona limnetik, dapat dilakukan penebaran ikan pemakan plankton sebanyak 4,118 juta ekor pada tahun pertama dan 1,235 juta ekor pada tahun berikutnya. Evaluasi keberasilan penebaran ikan di suatu badan air secara biologis ada tiga faktor, yaitu: (1) ikan yang ditebar harus dapat ditangkap kembali, (2) 
ikan yang ditebar harus mampu memanfaatkan sumber pakan alami yang tersedia dan (3) ikan tersebut harus mampu tumbuh cepat (Tjahjo, 2004).

\section{Dampak Sosial dan Kelembagaan}

Sebelum dilakukannya penebaran ikan Bandeng oleh Kementerian Kelautan dan Perikanan yang bekerja sama dengan ACIAR telah dilakukan hal yang sama oleh PJT II pada tahun 2007, namun kegiatan penebaran ini tidak terfokus pada Bandeng, jenis ikan yang ditebar antara lain adalah gurame, sepat, nilem dan Bandeng. Pada saat dilakukan penebaran oleh PJT II melibatkan juga masyarakat, pokwasmas dan Dinas Peternakan dan Perikanan Kabupaten Purwakarta.

Penebaran ikan Bandeng yang dilakukan oleh Kementerian Kelautan dan Perikanan yang bekerja sama dengan ACIAR dilakukan dalam 2 periode. Pada periode pertama yaitu pada tahun 2008, yang dilaksanakan pada bulan Juli - Agustus. Jumlah benih yang ditebar sesuai dengan program adalah sebanyak 2.000.000 ekor, namun jumlah benih yang terrealisasi untuk ditebar melebihi dari rencana awal yaitu sebanyak 2.116.000 ekor. Penebaran ini melibatkan masyarakat dan kelembagaan nelayan di Waduk Jatiluhur yaitu kelompok nelayan Mandiri Jaya dan pokwasmas Matahari. Selanjutnya penebaran pada periode kedua dilakukan pada tahun 2009 yang dibagi dalam beberapa tahapan selama 4 bulan (Oktober 2009 - Januari 2010). Jumlah benih yang ditebar sesuai dengan program pada periode kedua adalah sebanyak 10.000.000 ekor. Penebaran dilakukan pada 5 titik lokasi, yaitu wilayah Ancol, Galumpit, Pasir Gabruk, Cibinong dan Pasir Gombong. Sama halnya dengan penebaran pada periode pertama, kegiatan penebaran ini melibatkan masyarakat dan kelompok nelayan. Setiap lokasi penebaran dikoordinatori oleh para ketua kelompok pokmaswas dan kelompok nelayan yang berada dekat lokasi penebaran.

Adapun permasalahan yang dihadapi selama proses penebaran dilakukan antara lain adalah, pada periode pertama (tahun 2008) yaitu kurang siapnya kelembagaan nelayan sebagai motor penggerak bagi pengelolaan SDI dalam mendukung program ini khususnya upaya pendampingan melalui pembinaan yang kontinu mengenai pengetahuan dan ketrampilan teknis dalam melaksanakan kegiatan pemantauan ikan tebaran, sehingga pencatatan hasil tangkapan Bandeng sangat minim, dan kurang dapat terpantau. Selain itu sosialisasi yang dilakukan secara kurang menyeluruh, telah berdampak pada kesimpangsiuran informasi yang diterima oleh masyarakat perikanan terkait sehubungan dengan aktifitas penebaran. Bahkan tidak sedikit masyarakat yang dengan sengaja untuk kepentingannya sendiri, melakukan pelanggaran dengan melakukan kegiatan "ngampleh" (penangkapan benih Bandeng dengan mengunakan jaring KJA yang diturunkan dengan cara menjebak).

Pada proses penebaran periode kedua tahun 2009/2010, permasalahan yang dialami antara lain adalah pada kendala pengawasan yang menjadi kendala utama dalam pelaksanaan program penebaran Bandeng 10 juta ekor. Kendala tersebut meliputi minimnya lembaga pengawas (pokwasmas) untuk menjangkau seluruh wilayah perairan waduk, serta belum terlalu dikuasainya teknik pengawasan serta kemampuan pengetahuan dari pelaksanan pengawas lapang yang terdiri dari anggota pokmaswas serta kelompok nelayan terhadap aturan-aturan terkait pengawasan dan tindakan terhadap indikasi pelanggaran. Akibatnya akifitas pengawasan justru tidak jarang menuai konflik antar nelayan di perairan waduk, sehingga memerlukan perhatian cukup serius bagi upaya penyelesaiannya.

Program Penebaran ikan Bandeng dinilai cukup mampu meningkatkan aktifitas dan efektifitas fungsi kelembagaan masyarakat perikanan, yang dicirikan:

\section{a. Kelembagaan input jasa/sarana produksi}

Ketersediaan dan jumlah sarana produksi pada lokasi penelitian sangat memadai dan mudah dijangkau sehingga jika responden memerlukan sarana produksi kapanpun selalu 
tersedia. Untuk lokasi kelembagaan input seperti perahu dan alat tangkap berada di Desa Panyindangan dan lingkup Kecamatan Sukatani, namun untuk ketersediaan kelembagaan input mesin berada di Kota Kabupaten (Purwakarta) dan Kota lainnya seperti Bandung, Jakarta, Cikampek dan Karawang.

\section{b. Kelembagaan tenaga kerja}

Kelembagaan tenaga kerja tidak didapatkan dilokasi perikanan, karena usaha penangkapan ikan adalah tradisional dan hanya dilakukan seorang diri (tidak memerlukan anak buah kapal).

\section{c. Kelembagaan Permodalan}

Kelembagaan permodalan yang ada adalah kelembagaan permodalan informal seperti juragan maupun pedagang pengumpul yang tidak hanya memenuhi kebutuhan operasional usaha tetapi juga kebutuhan harian pembudidaya maupun nelayandan keluarganya.

\section{d. Kelembagaan pemasaran hasil}

Sebagian besar nelayan biasanya menjual hasil tangkapan kepada juragan (bandar), pedagang pengumpul (pedagang keliling) maupun konsumen langsung. Tidak ditemui kelembagaan pemasaran hasil secara khusus, namun sebagian responden sudah memiliki ikatan bisnis dengan para bandar maupun pedagang pengumpul. Nelayan langsung memasarkan hasil tangkapan kepada bandar maupun pedagang pengumpul. Bentuk produk yang dijual adalah ikan hidup dan ikan segar dengan pembayaran secara tunai.

\section{e. Kelembagaan kelompok dan penyuluh}

Ada beberapa kelembagaan kelompok nelayan tangkap yang ditemui pada lokasi penelitian, antara lain Himpunan Nelayan Jatiluhur (HINPUJAT) dan kelompok Himpunan Pengumpul Hasil Tangkapan Nelayan Jatiluhur (PULTANUR). Kegiatan kelompok nelayan ini antara lain adalah pengaturan ukuran mata jaring, penentuan harga ikan dan masalahmasalah yang terkait penangkapan ikan. Sementara untuk kegiatan penyuluhan dilakukan oleh Dinas Perikanan Kabupaten Purwakarta melalui tenaga penyuluhnya, antara lain Penyuluh Perikanan Tenaga Kontrak (PPTK). Jika responden mendapatkan masalah mengenai usaha penangkapan, maka responden mencari informasi kepada rekan sesama nelayan, anggota kelompok maupun kepada penyuluh (PPTK) perikanan.

Hampir 80 persen dari total masyarakat nelayan dan pembudidaya telah tergabung dalam kelompok nelayan dan pembudidaya yang tersebar di seluruh perairan waduk, baik yang secara resmi membentuk kelompok nelayan, maupun yang tergabung berdasarkan kelompok pengepul. Pada kelompok-kelompok nelayan dan pengepul telah memiliki dan melakukan pencatatan data produksi hasil tangkapan ikan secara baik dalam log book, sehigga informasi mengenai perkembangan produksi perikanan tangkap di perairan dapat diketahui dan dipantau secara menyeluruh dan kontinu. Selain itu sebagian besar nelayan juga telah memiliki kesadaran yang tinggi untuk tidak menggunakan alat tangkap merusak/ tidak ramah lingkungan. Hal tersebut juga juga tidak terlepas dari adanya perubahan persepsi masyarakat terhadap program penebaran sebagai dampak dari sosialisasi pelaksanaan penebaran yang dilakukan secara menyeluruh.

Pada penebaran tahap I, hanya dilakukan pada satu titik penebaran (zona limnetik) dan hanya melibatkan secara langsung satu lembaga/kelompok nelayan, sehingga moniroting terhadap keberhasilan penebaran baik berupa catatan hasil tangkapan maupun pertumbuhan ikan, menjadi kurang terpantau. Pada penebaran tahap II, dilakukan secara lebih menyeluruh di seluruh wilayah perairan waduk dengan melibatkan perwakilan lembaga/ kelompok nelayan pada masing-masing titik secara langsung, berdampak pada aktifitas monitoring yang berjalan cukup baik, sehingga catatan keberhasilan penebaran menjadi lebih terpantau. 
Pada kelompok pembudidaya khususnya kelompok binaan, telah mulai menerapkan sistem budidaya ramah lingkungan dengan cara menjaga kebersihan lingkungan budidaya, meskipun dalam implementasi belum berjalan secara menyeluruh pada seluruh pembudidaya di perairan, dimana sebagian besar pembudidaya karena alasan ekonomi masih menggunakan pakan tidak ramah lingkungan (mie dan roti bekas).

Pada kelompok pokmaswas, diketahui bahwa pada kelompok pokmaswas yang telah terbentuk lama (kelompok Matahari), hampir tidak menemui kendala berarti dalam menjalankan tugas sesuai keputusan yang disepakati, namun pada kelompok pokwasmas baru (Galumpit), kendala terletak pada wilayah pengawasan yang cukup luas, minimnya anggota pelaksana pengawas, dan kurangnya pengetahuan pelaksana mengenai tata aturan teknis pelaksanaan pengawasan, sehingga sering penanganan kasus pelanggaran yang kurang tepat berujung pada munculnya konflik baru antar masyarakat perikanan.

\section{Dampak Ekonomi}

\section{Mata Pencaharian}

Berdasarkan data responden yang diperoleh pada lokasi penelitian, jenis mata pencaharian utama masyarakat sebagai nelayan, adapun mata pencaharian sampingannya adalah bercocok tanam, buruh tani, pengrajin perahu/bengkel, pembudidaya ikan nila dan buruh bangunan. Besarnya persentase untuk setiap jenis mata pencaharian antara lain yaitu, untuk jenis mata pencaharian utama sebagai nelayan saja sebanyak $47 \%$, mata pencaharian nelayan dengan sampingan bercocok tanam sebesar $20 \%$, mata pencaharian nelayan dengan sampingan sebagai buruh tani sebesar $13 \%$, mata pencaharian nelayan dengan sampingan sebagai pengarajin perahu/bengkel sebesar $10 \%$, mata pencaharian nelayan dengan sampingan sebagai pembudidaya ikan nila sebesar $7 \%$ dan mata pencaharian nelayan dengan sampingan sebagai buruh bangunan sebesar 3\% (Tabel 3).

Berdasarkan hasil verifikasi lapang, semenjak dilakukannya penebaran ikan Bandeng di waduk Jatiluhur banyak masyarakat sekitar waduk Jatiluhur yang beralih profesi menjadi nelayan maupun pedagang pengumpul/ bandar ikan. Hal ini didukung oleh data yang diperoleh dari Dinas Peternakan dan Perikanan Kabupaten Purwakarta, bahwa adanya peningkatan jumlah nelayan pada tahun 2009 sebanyak 461 orang dibandingkan tahun sebelumnya. Tentu saja hal ini mungkin lebih sedikit jika dibandingkan dengan kenyataan di lapang, karena banyaknya masyarakatnya

Tabel 3. Proporsi Penduduk Berdasarkan Jenis Mata Pencaharian di Desa Panyindangan, Waduk Jatiluhur, 2010.

Table 3. Proportion of Residential Household According to Livelihood Type in the Panyindangan Village of Jatiluhur Reservoir, 2010.

\begin{tabular}{lc}
\multicolumn{1}{c}{ Jenis Pekerjaan/ Livelihood Type } & $\begin{array}{c}\text { Persentase/ } \\
\text { Percentage (\%) }\end{array}$ \\
\hline Nelayan/ Fishers & 47 \\
Nelayan + Bercocok Tanam (Padi)/ Fishers + Farmers (Paddy) & 20 \\
Nelayan + Buruh Tani/ Fishers+Farmer Workers & 13 \\
Nelayan + Bengkel/Pengrajin Perahu/ Fishers+Workshop/Craftsmen Boat & 10 \\
Nelayan + Budidaya Ikan Nila/ Fishers+ Tilapia Fish Culturer & 7 \\
Nelayan + Buruh Bangunan/ Fishers + construction workers & 3 \\
\hline \multicolumn{2}{c}{ Jumlah/ Total } \\
\hline
\end{tabular}

Sumber : Data Primer diolah, 2010.

Source : Primary Data Processed, 2010. 
yang beralih profesi menjadi nelayan dadakan yang tidak tercatat. Proses peralihan profesi pekerjaan atau mata pencaharian masyarakat yang sebelumnya bekerja di luar perikanan maupun sebagai pembudidaya menjadi nelayan akibat adanya penebaran ikan Bandeng memberikan dampak sosial yang cukup besar dimasyarakat. Puncaknya terjadi pada saat dilakukannya panen raya Januari - Februari 2010.

Banyak masyarakat yang menjual harta yang dimiliki untuk dapat membeli alat tangkap (jaring) untuk menangkap Bandeng, dan tidak jarang pula yang meminjam uang baik kepada lembaga permodalan formal maupun informal. Tentu saja dari hal tersebut ada yang mendapatkan keuntungan maupun kerugian. Pihak-pihak yang diuntungkan antara lain nelayan itu sendiri, para pengepul/bandar ikan dan juga para pihak yang berusaha di bidang pengolahan ikan (pengasapan/pengasinan). Pada awalnya nelayan memperoleh keuntungan dari hasil menangkap ikan Bandeng, namun dikarenakan semakin banyaknya jumlah masyarakat yang ikut turun ke waduk untuk menangkap ikan sehingga menimbulkan persaingan yang menyebabkan hasil tangkapan semakin menurun. Selain itu, karakter ikan Bandeng itu sendiri yang memiliki sifat dinamis sehingga sulit tertangkap dengan peralatan sederhana yang digunakan oleh nelayan.

Adapun beberapa permasalahan lain yang dialami oleh masyarakat yang memiliki matapencaharian di bidang perikanan (khususnya yang terkait dengan ikan Bandeng) antara lain, kualitas Bandeng tebaran, tingkat harga yang fluktuatif, dugaan dampak eksternalitas terhadap pertumbuhan ikan budidaya, serta biaya investasi alat tangkap yang sangat tinggi, secara rinci sebagai berikut:

1. Harga jual ikan Bandeng hasil tangkapan nelayan di Waduk Jatiluhur lebih rendah dibandingkan harga jual ikan Bandeng hasil budidaya. Salah satu penyebabnya yang dikemukakan oleh nelayan adalah ikan Bandeng hasil tangkapan nelayan, banyak yang rusak, seperti sisiknya banyak yang lepas, insangnya rusak dan sebagainya. Seperti dikemukakan oleh nelayan hal tersebut disebabkan karena ikan Bandeng yang terjerat jaring, dan waktu tertangkapnya ikan sampai dengan pengangkatan jaring cukup lama sehingga ikan ketika diangkat sudah dalam keadaan mati bahkan busuk. Mungkin beberapa hal ini yang menyebabkan kualitas ikan menurun dan harganya pun rendah dipasaran.

2. Sampai dengan minggu ke I, bulan juni 2010, para bandar (grocery) ikan di Jatiluhur mengalami kerugian ketika menjual/memasarkan ikan Bandeng hasil tangkapan. Rata-rata para bandar menanggung kerugian per/Kg ikan Bandeng sebesar Rp. 500,-. Seperti yang dikemukakan oleh Bapak. Kodir (bandar). Meskipun fluktuasi harga saat ini kembali membaik, namun belum diketahui pasti apakah dikarenakan mutu ikan yang membaik, atau karena pasokan ikan yang lebih sedikit.

3. Pada saat ini dirasakan perairan di waduk Jatiluhur terasa lebih "bersih" dari sebelumnya, nelayan beranggapan bahwa ini merupakan salah satu dampak positif dari penebaran ikan Bandeng yang bersifat "plankton feeder". Namun ada permasalahan, pada usaha budidaya pembesaran ikan nila yang dirasakan oleh nelayan bahwa ikan nila yang mereka pelihara "susah besar". Hal ini merupakan salah satu dampak dari penebaran ikan Bandeng yang memakan plankton, sehingga plankton yang ada, sudah habis dimakan oleh ikan Ba (ikemukakan oleh bapak. Warsidi, ketua kelompok budidaya).

4. Biaya investasi alat tangkap yang tidak sedikit bila dibandingkan dengan alat tangkap untuk ikan nila dan sebagainya, telah berdampak pada sulitnya nelayan mengembalikan biaya investasi, bahkan tidak jarang nelayan justru mengalami kerugian. 


\section{Pendapatan}

Penebaran ikan Bandeng belum mampu meningkatkan kesejahteraan masyarakat melalui peningkatan pendapatan dari hasil tangkapan ikan.

1. Kegiatan penangkapan ikan Bandeng bersifat musiman dan dilakukan secara panen raya. Dengan demikian pada musim tangkapan Bandeng tidak hanya nelayan tetap, namun nelayan musiman juga ikut melakukan aktifitas penangkapan. Akibat banyaknya yang terlibat penangkapan, hasilnya Bandeng menjadi kurang signifikan menaikkan pendapatan nelayan. Selain itu, biaya investasi alat tangkap yang cenderung lebih mahal dibanding alat tangkap untuk ikan nila, diiringi masa panen yang pendek, sulit bagi nelayan untuk mengembalikan modal investasi. Meskipun demikian, hasil wawancara terhadap beberapa nelayan juga menyatakan, bahwa pada saat panen Bandeng, hasil tangkapan harian mengalami peningkatan cukup signifikan. Di zona 3 misalnya, dari $1 \mathrm{~kg} /$ nelayan/ hari sebelum ada penebaran, pada saat penebaran dapat meningkat menjadi $2 \mathrm{~kg} /$ nelayan/hari, namun situasi tersebut tidak berlangsung lama.

2. Harga jual ikan Bandeng hasil tangkapan nelayan di Waduk Jatiluhur lebih rendah dibandingkan harga jual ikan Bandeng hasil budidaya. Salah satu penyebabnya yang dikemukakan oleh nelayan adalah ikan Bandeng hasil tangkapan nelayan, banyak yang rusak, seperti sisiknya banyak yang lepas, insangnya rusak dan sebagainya. Seperti dikemukakan oleh nelayan hal tersebut disebabkan karena ikan Bandeng yang terjerat jaring, dan waktu tertangkapnya ikan sampai dengan pengangkatan jaring cukup lama sehingga ikan ketika diangkat sudah dalam keadaan mati bahkan busuk., mungkin beberapa hal ini yang menyebabkan kualitas ikan menurun dan harganya pun rendah dipasaran. Dari permasalahan ini nelayan mengharapkan introduksi dari instansi terkait mengenai teknik penanganan hasil tangkapan maupun teknik penangkapan ikan yang baik agar tetap terjaga kualitasnya

3. Pada sebagian besar pembudidaya skala kecil (khususnya di zona 1, 2, 3), justru mengeluhkan penurunnya laju pertumbuhan komoditas budidaya khususnya ikan nila yang diduga ada kaitannya dengan adanya penebaran Bandeng, yang berakibat pada mundurnya masa panen.

Selain mempengaruhi pendapatan di sektor budidaya dan perikanan tangkap, adanya kegiatan penebaran ikan Bandeng telah menstimulir aktifitas pengolahan hasil perikanan, yakni pengolahan Bandeng menjadi produk olahan ikan pindang, dan ikan asin kering. Pengolahan ikan pindang banyak dilakukan oleh masyarakat Desa Galumpit, dan Pasir Kole, sedangkan produk asin Bandeng, dilakukan oleh masyarakat Desa Servis.

Di sektor pariwisata, aktivitas yang dinilai cukup signifikan mengalami peningkatan adalah aktivitas pemancingan. Di mana hasil identifikasi tahun 2003, tercatat hanya sekitar 40 unit pondok pemancingan, pada 2008 mengalami peningkatan hingga mencapai 1.050 unit, bahkan terus meningkat di 2009 hingga mencapai lebih dari 1.600 unit, yang tersebar mulai daerah Ubrug (zona 1) hingga Pasir Kole, dan sebagian kecil daerah Galumpit (di luar zona 5), kondisi ini menunjukkan bahwa program penebaran cukup mampu meningkatkan minat masyarakat untuk melakukan wisata mancing (sport fishing). Peningkatan jumlah pemancing berdasarkan hasil wawancara bukan disebabkan karena adanya penebaran Bandeng di Waduk Jatiluhur namun lebih disebabkan karena meningkatnya minat wisata pancing dari pengunjung. Hingga saat ini aktifitas ini belum mendapat perhatian serius oleh pemerintah dan instansi terkait untuk upaya pengelolaannya.

\section{Nilai Ekonomi Produksi Ikan Bandeng}

Pada kegiatan penebaran Bandeng tahap I (2 juta ekor), kegiatan monitoring keberhasilan 
dilakukan dengan melihat perkembangan pertumbuhan dan produksi Bandeng tebaran baik yang dilakukan oleh masyarakat secara langsung (nelayan dan kelompok nelayan) maupun yang dilakukan oleh Badan Riset Pemulihan Sumber Daya Ikan (BRPSI) selaku institusi riset terkait. Pengamatan terhadap hasil tangkapan ikan Bandeng hanya dapat dipantau pada satu titik pengamatan (dilakukan kelompok nelayan Mandiri Jaya pada titik pendaratan ikan di Desa Cibinong) sesuai dengan keterlibatan anggota kelompok secara langsng dalam kegiatan penebaran. Hasilnya menunjukkan bahwa ikan Bandeng tebaran mulai tertangkap pada pertengahan bulan september 2008 (Gambar 1). Populasi ikan Bandeng yang tertangkap sangat mempengaruhi komposisi hasil tangkapan beberapa jenis ikan dominan yang selama sering tertangkap oleh nelayan, di mana selama 6 bulan pengamatan yakni September 2008 - Februari 2009, ikan Bandeng menempati urutan ketiga setelah ikan nila dan jambal (Gambar 2). Bahkan pada bulan Oktober jenis Bandeng merupakan ikan

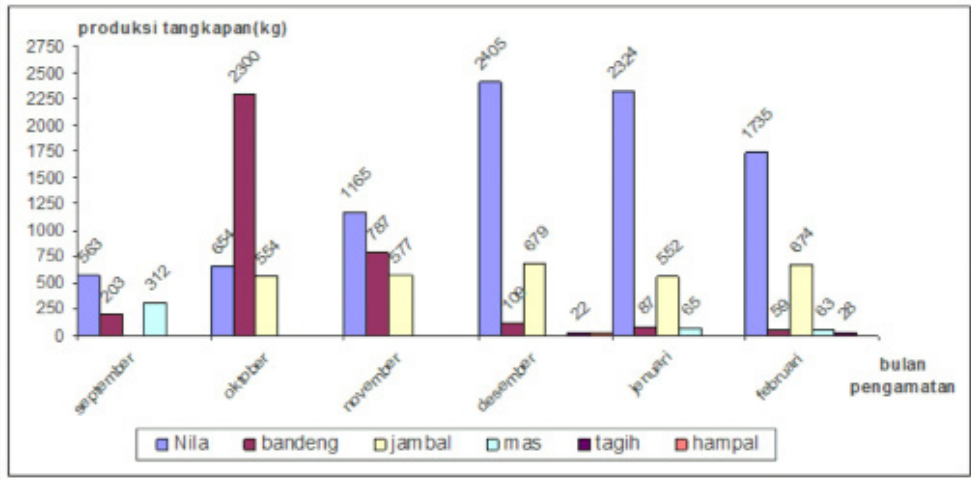

Gambar 1. Grafik Komposisi Total Hasil Tangkapan Beberapa Jenis Ikan Berdasarkan Bobot di Waduk Jatiluhur, 2008-2009.

Figure 1. Graph of the Composition of Total Various-Fish Caught Based on Weight in the Jatiluhur Reservoir, 2008-2009.

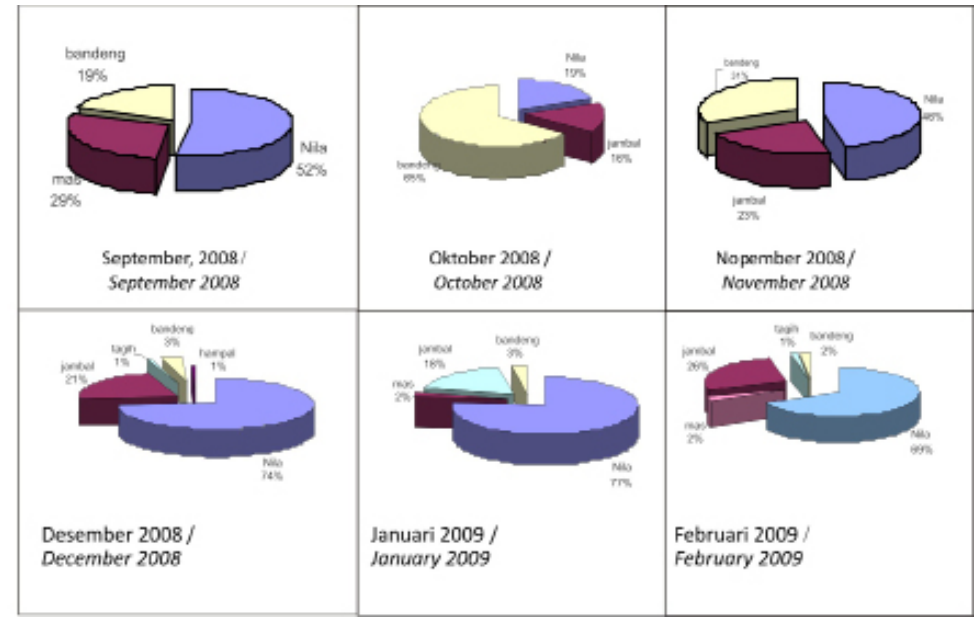

Gambar 2. Komposisi Hasil Tangkapan Ikan Dominan Tertangkap oleh Nelayan di Desa Cibinong, Jatiluhur.

Figure 2. Composition of the Dominant Fish Caught Fishers in the Cibinong Village of Jatiluhur Reservoir, 2008-2009. 
yang paling banyak tertangkap oleh nelayan. Namun pada bulan Maret, ikan Bandeng sudah hampir tidak ditemukan lagi.

Bulan oktober merupakan puncak produksi tangkapan ikan Bandeng, yakni sebesar $2.300 \mathrm{~kg}(65 \%)$ dari total tangkapan nelayan, yang juga merupakan puncak musim penangkapan. Kondisi tersebut ditunjukkan bahwa pada bulan tersebut rata-rata hasil tangkapan nelayan mencapai 9,7 kg/orang/ hari (Gambar 3).
Pertumbuhan ikan Bandeng tebaran menunjukkan bahwa ikan tersebut mampu tumbuh baik di perairan, di mana dari ukuran panjang dan bobot awal masing-masing 2,8-8,5 $\mathrm{cm}$ dan 0,1-5,1 gram. Ikan Bandeng tersebut tertangkap kembali pada bulan September, Oktober dan Desember masing-masing dengan ukuran 14,31,0 cm (67-342 gram), 20,7-32,5 $\mathrm{cm}$ (67-342 gram), 20,0-34,5 cm (66-347 gram) dan 23,0-31,0 cm (95-230 gram) menunjukkan laju pertumbuhan yang cepat.

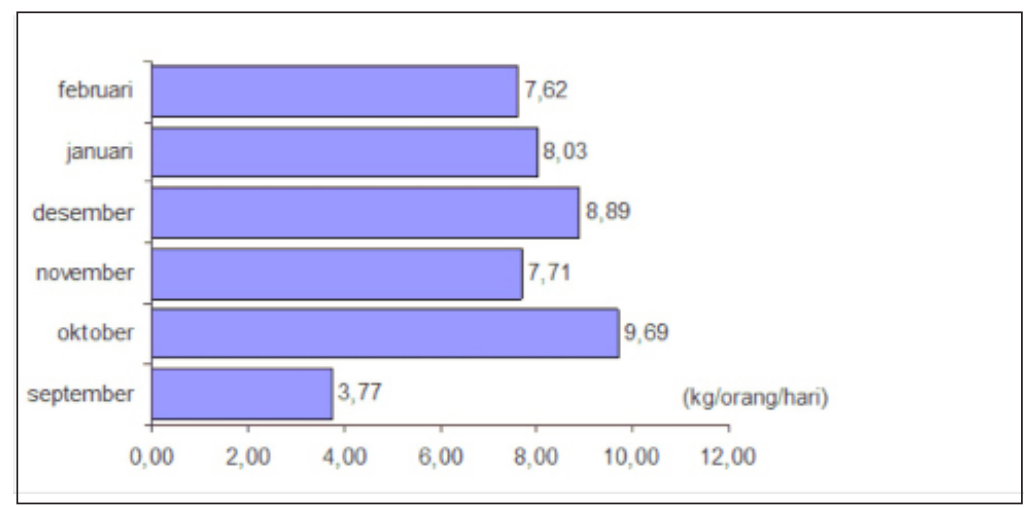

Gambar 3. Rata-Rata Hasil Tangkapan Nelayan Desa Cibinong Berdasarkan Bulan Pengamatan di Waduk Jatiluhur, 2008-2009.

Figure 3. Average Daily Fish Caught by Fisher in the Cibinong Village of Jatiluhur Reservoir, 2008-2009.

Tabel 4. Jumlah dan Ukuran Panjang Total dan Bobot Benih Bandeng yang Ditebar dan Ditangkap Menurut Waktu Pengamatan di Waduk Jatiluhur, 2008.

Table 4. Number and Size of Total Length and Weight of Milkfish Seed Being Stocked and Recapture During Observation Period in Jatiluhur Reservoir, 2008.

\begin{tabular}{lcccccc}
\hline \multirow{2}{*}{ Parameter } & \multicolumn{3}{c}{$\begin{array}{c}\text { Benih Yang Ditebar/ } \\
\text { Stocking Seed }\end{array}$} & \multicolumn{3}{c}{ Hasil Ikan Yang Ditangkap Fish Captured } \\
& Jul & Aug & Sept & Okt & Nov & Dec \\
\hline JUMLAH(ekor)/ Total (Fish) & $2,116,000$ & 61 & 35 & 38 & 54 \\
PANJANG (cm)/ Length (cm) & & & & & & \\
Rataan/ Average & 5.8 & 4.7 & 23.7 & 27.3 & 26.9 & 27.5 \\
min & 3.2 & 2.8 & 14.7 & 20.7 & 20.0 & 23.0 \\
max & 7.8 & 8.5 & 31 & 32.5 & 34.5 & 31.5 \\
BOBOT/ Weight & & & & & & \\
Rataan/ Average & 1.3 & 0.8 & 134 & 179 & 158 & 159 \\
min & 0.3 & 0.1 & 25 & 67 & 66 & 95 \\
max & 3.3 & 5.1 & 280 & 342 & 347 & 230 \\
\hline
\end{tabular}

Sumber : LRPSI, 2008.

Source : LRPSI, 2008. 
Kegiatan penangkapan Bandeng tebaran di mulai pada tanggal 31 januari 2010. Selama periode Januari-Juli 2010, berdasarkan data yang tercatat secara rutin pada pada 16 pengumpul (10 pengepul aktif) di seluruh titik pendaratan, diketahui bahwa total tangkapan Bandeng tebaran telah mencapai 23.140,7 $\mathrm{kg}$ atau sebesar 23,1407 ton atau 0,12 \% dari total Bandeng yang telah di tebar. Pada penebaran tahap I, hasil pemantauan terhadap nilai ekonomi ikan Bandeng, menunjukkan bahwa komoditi tangkapan tersebut cukup memiliki nilai ekonomi yang tinggi. Ditingkat konsumen akhir, harga ikan ini dapat mencapai $\mathrm{Rp} 14.000 / \mathrm{kg}$. Satu nilai yang cukup tinggi bahkan melampaui harga ikan yang dominan tertangkap di Jatiluhur yaitu ikan nila, di mana di tingkat konsumen hanya mencapai Rp.10.000/kg atau sekitar Rp 7.000-9.000/kg di tingkat nelayan. Namun di tingkat nelayan ikan Bandeng hasil tangkapan dengan ukuran antara 300-350 gram/ekor, harga jualnya hanya berkisar antara Rp. 6.000-7.000/kg saja. Namun demikian, biasanya nelayan tetap menjualnya dengan harga murah, disebabkan karena sifat ikan jenis ini yang mudah busuk.

Pada penebaran tahap II, hasil pemantauan terhadap nilai ekonomi ikan Bandeng, menunjukkan bahwa harga ikan Bandeng cukup berfluktuasi. Ikan tebaran tersebut pada awalnya cukup memiliki nilai ekonomi yang tinggi meskipun tidak sebaik harga jual pada periode penebaran tahap 1 (2008), di mana ditingkat konsumen harga ikan ini dapat mencapai Rp 14.000/kg. Pada penebaran tahap 2 harga di tingkat konsumen hanya mencapai 9000-9500/ kg untuk yang berkualitas baik, dan 8000$8500 / \mathrm{kg}$ untuk kualitas sedang. Di tingkat nelayan, para pengepul menghargai Bandeng tangkapan dengan harga $6.000 / \mathrm{kg}$. Dalam pekembangannya, harga ikan Bandeng Waduk Jatiluhur semakin menurun, terkait dengan kualitas/mutu Bandeng yang dihasilkan, sampai bulan Mei 2010 harga Bandeng mencapai titik terendah yakni Rp 5000-5500/kg di tingkat nelayan. Hasil interview kepada sejumlah pengepul menyatakan bahwa kualitas Bandeng waduk lebih rendah dibandingkan dengan
Bandeng yang berasal dari tambak. Bandeng tangkapan bercirikan mudah busuk, dengan sisik yang mudah terkelupas. Selain itu, persentase tangkapan terbesar justru berukuran relativ kecil 150-200 gr/ekor, sehingga menjadi kurang memiliki nilai ekonomis. Namun demikian, pada awal juli 2010, harga Bandeng kembali naik antara 7000-8000 di tingkat pengepul.

Perkembangan produksi Bandeng berimplikasi pada besarnya nilai retribusi Bandeng yang disepakati yakni sebesar Rp 600/kg Bandeng dengan perincian Rp 200/ $\mathrm{kg}$ di tingkat nelayan, Rp 200/kg di tingkat pengepul kecil, dan Rp 200/kg di tingkat pengepul besar/bandar. Sampai dengan bulan Mei 2010, telah terkumpul retribusi Bandeng sebesar Rp 8.397.400, yang kemudian di simpan pada lembaga keuangan atas nama kelompok Pultanur, sebagai tabungan penebaran.

\section{Perhitungan Biaya dan Manfaat}

Estimasi perhitungan biaya dan manfaat dari kegiatan penebaran Bandeng di waduk Jatiluhur dapat diilustrasikan pada Tabel 5.

Dengan mengacu pada estimasi perhitungan biaya manfaat, di mana dugaan ikan tertagkap kembali pada saat panen sebesar $30 \%$ dari total benih yang di tebar (Kartamihardja et al., 2003) saja, maka kegiatan penebaran dengan biaya investasi sebesar Rp 2.5 milyar, mampu memberikan penerimaan sebesar Rp 5,4 milyar, dan memberikan manfaat besih sebesar Rp 2,9 milyar.

\section{ESTIMASI KEBIJAKAN PENGEMBANGAN KE DEPAN}

Penebaran ikan Bandeng secara sistematis di Waduk Jatiluhur telah dilakukan sejak tahun 2008 melalui rekomendasi project kerjasama antara Kementerian Kelautan dan Perikanan dan Australian Center for International Agricultural Research (ACIAR). Penebaran di bagi dalam dua tahap, yakni, tahap I tahun 2008, dilaksanakan selama kurun waktu 1 bulan (Juli-Agustus 2008) sebanyak 2.116.000 ekor, dan tahap dua tahun 
Tabel 5. Perhitungan Biaya dan Manfaat Program Penebaran Ikan Bandeng di Waduk Jatiluhur. Table 5. Calculated of Cost and Benefit of Milfish Stocking Program in the Jatiluhur Reservoir.

\begin{tabular}{lc}
\multicolumn{1}{c}{ Kategori/ Category } & Nilai/ Value \\
\hline - Benih ikan Bandeng yang ditebar (ekor)/ & $10,000,000$ \\
Milkfish seed being stocked (fish) & 250 \\
- Harga benih (Rp/ekor)/ Seed price (IDR/seed) & 250 \\
\hline
\end{tabular}

Biaya/ Cost:

- $\quad$ Total investasi (Rp)/ Investment cost (IDR)

$2,500,000,000$

Manfaat/ Benefit*):

- $\quad$ Ikan Bandeng tertangkap nelayan (\%)/

30

Re-capture of milkfish (\%)

- $\quad$ Rataan berat ikan Bandeng tertangkap (kg/ekor)/ Average

0.3 weight of fish caught $(\mathrm{kg} /$ fish)

- Total ikan Bandeng tertangkap oleh nelayan (kg)/ Total 900,000 milkfish caught by fisher $(\mathrm{kg})$

- Harga ikan Bandeng (Rp/kg)/ 6,000

Price of milkfish (IDR/kg)

- Nilai total tangkapan ikan Bandeng (Rp)/ 5,400,000,000

Total value of harvested milkfish (Rp)

Manfaat Bersih (Rp)/Net Benefit (IDR)

$2,900,000,000$

*) : asumsi mengikuti Kartamihardja et al. (2003).

2009 yang direncanakan diselesaikan dalam kurun waktu 4 bulan (Oktober- Januari 2010) sebanyak 10.000 .000 ekor. Namun dalam implementasinya, hingga saat ini tahap dua baru terealisasi sekitar 4.787.231 ekor $(47,8 \%)$ dari total benih yang akan ditebar.

Penebaran ikan Bandeng tersebut memberikan dampak terhadap aspek ekologi sumber daya perairan waduk, aspek ekonomi dan aspek sosial masyarakat. Secara ekologi, penebaran ikan Bandeng ternyata memberikan dampak yang positif yaitu memperbaiki kualitas perairan waduk. Hal ini dapat dilihat dari tidak terjadinya kematian massal ikan akibat upwelling pada tahun 2010 yang biasanya terjadi pada bulan Januari - Februari. Banyak masyarakat yang beranggapan bahwa fenomena tersebut tidak terjadi setelah dilakukannya penebaran ikan Bandeng. Secara biologis ikan Bandeng bersifat plankton feeder, yang mungkin secara alami dapat mengurangi blooming algae yang menjadi salah satu penyebab upwelling, selain itu juga ada yang beranggapan bahwa hal tersebut dikarenakan tingginya permukaan air di Waduk Jatiluhur tinggi akibat musim hujan yang lebih lama dari biasanya. Tentu saja beberapa anggapan tersebut perlu pengkajian ilmiah untuk mengetahui penyebab pastinya.

Secara ekonomi, penebaran Bandeng di Waduk Jatiluhur juga memberikan dampak positif terhadap peningkatan pendapatan nelayan namun peningkatannya hanya berlangsung singkat. Ikan Bandeng dapat tumbuh dengan cepat bila dibanding dengan di pelihara pada habitat aslinya (air bersalinitas). Meskipun demikian, ikan Bandeng dalam perkembangannya memiliki keterbatasan tidak dapat berkembangbiak secara alami di perairan tawar, sehingga untuk keberlanjutannya diperlukan sistem penebaran ulang secara periodik. Sifat biologis ini mengakibatkan nelayan hanya dapat memanfaatkan sumber daya ikan ini dalam waktu yang relatif pendek (pada saat penen raya), dan tidak 
ada keberlanjutan lagi jika tidak dilakukan restocking secara periodik. Kuallitas ikan Bandeng yang dihasilkan pun kurang baik, berbeda dengan Bandeng yang dihasilkan dari perairan payau. Ikan Bandeng yang ditangkap nelayan memiliki daging yang tidak kenyal/ lembek, sehingga harga jual dipasaran relatif rendah yaitu hanya berkisar Rp. $5.000 \mathrm{~s} / \mathrm{d}$ Rp. 6.000 per kg. Peningkatan pendapatan yang diperoleh nelayan tampaknya tidak dirasakan secara langsung oleh pembudidaya. Hal ini dikarenakan setelah adanya penebaran Bandeng ternyata ikan budidaya baik mas maupun nila pertumbuhannya lambat. Namun disisi lain pembudidaya tetap mendapatkan keuntungan dengan tidak adanya upwelling yang bisa mengakibatkan kematian masal ikan. Kajian secara ilmiah lebih lanjut harus dilakukan mengenai penyebab lambatnya pertumbuhan ikan budidaya masyarakat, apakah memang dikarenakan penebaran Bandeng atau karena faktor lainnya seperti kualitas benih yang kurang baik, pemberikan pakan maupun faktor lainnya.

Dari aspek sosial, pembentukan kelembagaan semakin berkembang dengan adanya program penebaran Bandeng ini, seperti kelembagaan pemasaran, kelembagaan usaha penangkapan ikan dan kelembagaan penyuluhan. Dengan terbentuknya kelompokkelompok nelayan maka penerapan aturanaturan yang terkait dengan pengelolaan sumber daya perairan maupun sumber daya ikan lebih optimal. Aturan-aturan mengenai penggunaan ukuran mata jaring tertentu, larangan penggunaan alat tangkap yang bersifat merusak misalnya menggunakan listrik/setrum juga semakin minim dengan terbentuknya kelompok masyarakat pengawas (Pokmaswas). Dampak secara sosial juga berimbas pada bermunculan nelayan baru atau mantan nelayan yang kembali melakukan usaha penangkapan ikan. Namun sayangnya, jumlah nelayan baru setelah adanya kegiatan penebaran ikan Bandeng ini tidak terdata dengan baik, berdasarkan hasil wawancara dengan informan kunci jumlah nelayan yang baru dan mantan nelayan yang kembali melakukan penangkapan ikan mencapai lebih dari seratus orang.

Penelitian di lapang menunjukkan bahwa kegiatan penebaran Bandeng di Waduk Jatiluhur atau yang lebih dikenal dengan Waduk Jatiluhur memberikan dampak bagi sumber daya perairan serta kondisi sosial ekonomi masyakat pemanfaat sumber daya tersebut. Dampak yang ditimbulkan merupakan dampak positif meskipun ada indikasi pula dampak negatif yang dirasakan oleh masyarakat, namun hal ini perlu dilakukan kajian lebih lanjut. Berdasarkan pertimbangan-pertimbangan tersebut maka beberapa rumusan kebijakan yang dapat dihasilkan dan perlu untuk ditindak lanjuti adalah meliputi (1) segera dilakukan kajian secara ilmiah pengaruh penebaran ikan Bandeng terhadap pertumbuhan ikan budidaya, (2) perlu dilakukan ujicoba penebaran dengan jenis ikan lainnya yang mampu bereproduksi secara alamiah di perairan waduk, (3) peguatan kelembagaan yang sudah ada terutama untuk kelompok masyarakat pengawas (POKMASWAS), serta (4) melakukan sosialisasi lebih intensif mengenai perlunya kesadaran masyarakat untuk menjaga kelestarian sumber daya perairan melalui penangganan limbah domestik rumah tangga serta tujuan dari kegiatan restocking yang diharapkan kedepan dapat dilakukan secara mandiri oleh masyarakat.

\section{PENUTUP}

Kegiatan penebaran ikan telah lama dipraktekan oleh penentu kebijakan teknis bidang perikanan baik ditingkat pusat, propinsi maupun kabupaten/kota; tetapi, seringkali terjadi kurang didasarkan atas pertimbangan ilmiah dan belum atau tidak dilakukan monitoring dan evaluasi paska penebaran. Untuk menjamin pencapaian tujuan dari kegiatan penebaran, hal utama yang perlu diperhatikan adalah mempedomani pelaksanaan penebaran sesuai dengan protokol kegiatan penebaran ikan pada sumber daya perairan tertentu yang telah ada dengan melibatkan partisipasi masyarakat secara aktif. 


\section{DAFTAR PUSTAKA}

ACIAR. Panduan Teknis Pengelolaan Perikanan Secara Bersama Pada perairan Waduk di Indonesia. Departemen Kelautan dan Perikanan (DKP) dan Australian center for International Agricultural Research (ACIAR). Jakarta.

BRPSI. 2009. Biolimnologi dan Hidrologi Waduk Kaskade Sungai Citarum, Jawa Barat. Laporan Hasil Penelitian Balai Riset Pemulihan Sumberdaya Ikan. (un publish).

Dinas Peternakan dan Perikanan Kabupaten Purwakarta. 2009. Laporan Tahunan Dinas Peternakan dan Perikanan, Kabupaten Purwakarta Tahun 2009. Kabupaten Purwakarta.

Kartamihardja, E.S. dan Hardjamulia, A. 1983. Kontribusi Penebaran Ikan Nila (Oreochromis Niloticus) Terhadap Produksi Ikan Di Waduk Jatiluhur, Jawa Barat. Bull. Pen. Perik. Darat. 4 (1):37-40.

Kartamihardja, E.S. and C. Umar. 2005. Capture Fisheries Component: Culture, Capture Conflicts, Sustaining Fish Production And Livelihoods. The $2^{\text {nd }}$ Quarter ACIAR project. (unpublish).

Kartamihardja, E.S. 2007. Spektra Ukuran Biomassa Plankton dan Potensi Pemanfaatanya Bagi Komunitas Ikan di Zona Limnetik Waduk Ir. H. Djuanda, Jawa Barat. Disertasi Doktor. Fakultas Pascasarjana, IPB. 137 hal. (un publish).

Krismono., K. Adriani, S.N dan A Hardjamulia. 1983. Penelitian Populasi Ikan di Waduk Jatiluhur Jawa Barat. Buletin Penelitian Perikanan Darat. Vol.4 No.2, Hal 50-53.
LRPSI. 2008. Bio,imnologi dan Hidrologi Waduk Kaskade Sungai Citarum, Jawa Barat. Laporan Akhir Riset (un publish). Loka Riset Pemacuan Stok Ikan Jatiluhur.

Nastiti, A.S., Krismono dan E.S. Kartamihardja. 2001. Daya dukung Perairan Waduk Jatiluhur untuk budidaya ikan dalam KJA. J. Penelitian Perikanan Indonesia. 7(2):14-21.

Nazir, M. 1988. Metode Penelitian. Ghalia Indonesia. Jakarta.

Sarnita, A. S., 1976. Some Aspects Of Fisheries And Their Development In Man-Made Lakes In Indonesia, With Special Reference To Lake Jatiluhur West Java. IPFC/76/ SYM/22. $21 \mathrm{p}$.

Sarnita, A.S. 1999. Introduction and stocking of freshwater fishes into inland waters of Indonesia. I W.L.T. van Densen \& M.J. Morris (eds) Fish and Fisheries of lakes and reservoirs in Shoutheast Asia and Africa. Westbury Publishing, Otley, UK. Pp. 143-150.

Sutardjo, 2000. Pengaruh budidaya ikan pada kualitas aiwaduk: Studi kasus pada budidaya ikan dalam keramba jaring apung di Ciganea, Waduk Jatiluhur Purwakarta Jawa Barat. Thesis. Tidak Dipublikasikan. Universitas Indonesia. Fakultas Pasca sarjana. Ilmu Lingkungan. Jakarta.

Tjahjo, D.W.T. 2004. Kemantapan Hasil Tangkapan, Keterkaitannya dengan Sintasan, Pertumbuhan dan Intensitas Penangkapan Udang Galah (Macrobrachium rosenbergii) yang ditebarkan di Waduk Darma, Kuningan-Jawa Barat. Disertasi Doktor. Fakultas Pascasarjana, IPB. 148 hal. Tidak dipublikasikan. 